\title{
Digenean parasites of Ciconiiform birds from Argentina
}

\section{Digéneos parásitos de aves Ciconiiformes de Argentina}

\author{
Fabiana B. Drago* and Lía I. Lunaschi \\ Laboratorio de Helmintología, División Zoología Invertebrados, Museo de La Plata, Facultad de Ciencias Naturales y Museo, Paseo del Bosque S/N ${ }^{o}$, \\ 1900 La Plata, Buenos Aires, Argentina. \\ *Correspondent:fdrago@fcnym.unlp.edu.ar
}

\begin{abstract}
The helminthological survey of 13 specimens of 5 ciconiiform species revealed the presence of 10 species of intestinal digeneans: Sphincterodiplostomum musculosum Dubois, 1936 in Tigrisoma lineatum and Ardea alba; Tylodelphys elongata (Lutz, 1928) in T. lineatum; Apharyngostrigea ardearum (Lutz, 1928) and Dolichorchis lacombeensis Lunaschi and Drago, 2006 in Ardea cocoi and Ardea alba; Posthodiplostomum nanum Dubois, 1937 in A. alba and T. lineatum; Ascocotyle diminuta (Stunkard and Haviland, 1924) in A. alba; Petasiger sp.1 in A. cocoi and Paryphostomum segregatum Dietz, 1909, Strigea vaginata (Brandes, 1888) and Petasiger sp. 2 in Coragyps atratus. Syrigma sibilatrix was free of digeneans. The reports of A. ardearum, T. elongata, S. musculosum and D. lacombeensis represent new host records; the other reports are new geographical records. Moreover, the specimens described as Apharyngostrigea brasiliana Szidat, 1929 by Labriola and Suriano (1998) were analyzed and transferred to $A$. ardearum.
\end{abstract}

Key words: Digenea, Ardeidae, Cathartidae, Strigeidae, Diplostomidae, Echinostomatidae, Heterophyidae.

Resumen. El estudio parasitológico de 13 ejemplares pertenecientes a 5 especies de aves Ciconiiformes reveló la presencia de 10 especies de digéneos intestinales: Sphincterodiplostomum musculosum Dubois, 1936 en Tigrisoma lineatum y Ardea alba; Tylodelphys elongata (Lutz, 1928) en T. lineatum; Apharyngostrigea ardearum (Lutz, 1928) y Dolichorchis lacombeensis Lunaschi y Drago, 2006 en Ardea cocoi y A. alba; Posthodiplostomum nanum Dubois, 1937 en A. alba y T. lineatum; Ascocotyle diminuta (Stunkard y Haviland, 1924) en A. alba; Petasiger sp.1 en A. cocoi y Paryphostomum segregatum Dietz, 1909, Strigea vaginata (Brandes, 1888) y Petasiger sp. 2 en Coragyps atratus. Syrigma sibilatrix no se encontró parasitada por digéneos. El presente estudio aporta nuevos registros de hospedadores para $A$. ardearum, T. elongata, S. musculosum y D. lacombeensis y nuevos registros geográficos para las restantes especies. Además, los organismos descritos como Apharyngostrigea brasiliana Szidat, 1929 por Labriola y Suriano (1998) fueron analizados y transferidos a A. ardearum.

Palabras clave: Digenea, Ardeidae, Cathartidae, Strigeidae, Diplostomidae, Echinostomatidae, Heterophyidae.

\section{Introduction}

Although 30 species of ciconiiform birds (14 Ardeidae, 8 Threskiornithidae, 3 Ciconiidae, 5 Cathartidae) are distributed Argentina, the information about its digenean fauna is scarce. At present, 8 ardeid species [Tigrisoma lineatum (Boddaert), Bubulcus ibis (L.), Butorides striata (L.), Ardea alba L., Ardea cocoi L., Egretta thula (Molina), Ixobrychus involucris (Vieillot), Nycticorax nycticorax (L.)], 4 threskiornithid species [Ajaia ajaja (L.), Phimosus infuscatus (Lichtenstein), Plegadis chihi (Vieillot), Theristicus caudatus (Boddaert)] and 2 ciconiid species [Ciconia maguari $(\mathrm{Gm})$ and Mycteria americana

Recibido: 17 agosto 2009; aceptado: 06 febrero 2010
L.] have been reported as hosts of digeneans (Lunaschi et al., 2007; Drago and Lunaschi, 2008; Lunaschi and Drago, 2009). Most of these records were made on the basis of hosts proceeding from the Humid Pampas ecoregion or under captivity in Zoological Gardens.

The aim of this paper is to increase the knowledge of the diversity of digenean parasites from ciconiiform birds collected in the Humid Chaco and Humid Pampas ecoregions.

\section{Material and methods}

Thirteen birds were hunted with guns between 1999 and 2006 from 3 localities of Formosa Province (Bellaco stream 
[26 $6^{\circ} 14^{\prime} \mathrm{S} ; 58^{\circ} 07^{\prime} \mathrm{W}$ ] and La Marcela farm [26 $17^{\prime} 35^{\prime \prime} \mathrm{S}$;

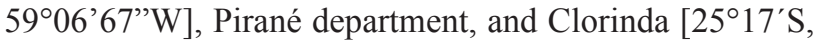
$57^{\circ} 43^{\prime} \mathrm{W}$ ], Pilcomayo department), and 1 from Buenos

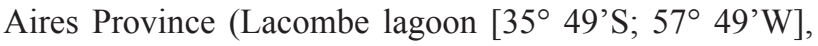
Lezama). The bird species analyzed were A. alba, A. cocoi, T. lineatum, Syrigma sibilatrix (Temminck) and Coragyps atratus (Bechstein). The viscera were fixed in 10\% formalin and examined for parasites in laboratory. The digenean specimens were stained with hydrochloric carmine, dehydrated and mounted in Canada balsam. The taxonomy of digeneans is given in accordance to Gibson et al. (2002), Jones et al. (2005) and Bray et al. (2008); identification of birds follows Barnett and Pearman (2001), and the parasitic indexes used were based on Bush et al. (1997). All digeneans were deposited in the Helminthological Collections of the Museo de La Plata (MLP), La Plata, Argentina, and the hosts in the Ornithological Collections of the Museo de La Plata (MLP).

\section{Results}

\section{Family Strigeidae \\ Strigea vaginata (Brandes, 1888) Szidat, 1928}

\section{Taxonomic summary}

Host: Coragyps atratus, black vulture (Cathartidae). Locality: La Marcela farm, Pirané, Formosa Province. Site of infection: intestine. Prevalence and mean intensity: 67\% (2 of 3); 3 (1-5). Voucher specimen deposited: MLP 5964.

\section{Remarks}

This species was briefly described as Holostomum vaginatum Brandes, 1888 from Cathartes sp. (Cathartidae) in Brazil, and transferred to $S$. vaginata by Szidat (1928). Later, it was reported parasitizing other Brazilian birds: $C$. atratus, Sarcoramphus papa (L.), Cathartes burrovianus urubitinga Pelzeln, (Cathartidae), Cariama cristata (L.) (Cariamidae), and Spizaetus ornatus (Daudin) (Accipitridae) (Szidat, 1929; Travassos et al., 1969). Strigea vaginata was also found parasitizing C. atratus and an indeterminate accipitrid (cited as "gavilán" and "gavião") in Venezuela (Lutz, 1928; Dubois, 1970a); Cathartes aura aura (L.) in Cuba (Dubois and Macko, 1972); Theristicus caudatus, Cercibis oxycerca (Spix) (Threskiornithidae), and Caracara plancus (Miller) (Falconidae) in Colombia (Dubois, 1978, 1981). According to Szidat (1929) and Dubois (1968), the specimens collected in the black vulture from Formosa Province were identified as $S$. vaginata mainly by the presence of an enormous copulatory bursa and genital cone, occupying almost half of the hindbody. This is the first report of $S$. vaginata in Argentina.

Apharyngostrigea ardearum (Lutz, 1928) Dubois, 1968 (Syn. Apharyngostrigea brasiliana Szidat, 1929 of Labriola and Suriano (1998): 3)

\section{Taxonomic summary}

Hosts and localities: Ardea alba from Lacombe lagoon, Lezama, Buenos Aires Province and Clorinda, Formosa Province; Ardea cocoi from Lacombe lagoon.

Site of infection: intestine.

Prevalence and mean intensity: A. alba, Lacombe lagoon: $50 \%$ (2 of 4); 10 (8-12); A. alba, Clorinda: 1 of $1 ; 33 ; A$. cocoi: $50 \%$ (1 of 2); 3 .

Voucher specimen deposited: A. alba MLP 5965 from Buenos Aires Province, MLP 5966 from Formosa Province; A. cocoi MLP 5967.

Other material: specimens from A. alba (MLP 5968) and B. ibis (MLP 5969) from Monte Lagoon, Buenos Aires Province [of Labriola and Suriano (1998)].

\section{Remarks}

The morphological features of the specimens studied herein correspond to the description of $A$. ardearum given by Dubois (1981). This species was previously reported parasitizing herons from Venezuela by Lutz (1928) (as Strigea ardearum Lutz, 1928), Ardea herodias herodias L. and Nycticorax n. hoactli (Gmelin) from Cuba by Pérez Vigueras (1944) [as Apharyngostrigea cornu (Zeder, 1800)]. Moreover, Ardea purpurea L. was reported as experimental host in Guadalupe (Dubois, 1981). At present, in Argentina only 1 species of Apharyngostrigea Ciurea, 1927, Apharyngostrigea simplex (Johnston, 1904), has been reported by Ostrowski de Núñez (1989) parasitizing E. thula from Buenos Aires Province.

In addition, specimens described as $A$. brasiliana were reported parasitizing A. alba, A. a. egretta and B. ibis from Buenos Aires Province (Boero et al., 1972; Labriola and Suriano, 1998). Nevertheless, this species was previously transferred by Dubois (1964) to Parastrigea Szidat, 1928. 
The specimens poorly described by Boero et al. (1972) do not show the main diagnostic characters of Parastrigea (e.i. vitelline follicles in forebody accumulated in 2 symmetrical masses localized in lateral expansions of dorsal lobe of holdfast organ). Unfortunately, their correct identification cannot be reviewed because no specimens were deposited at the appropriate time. The re-examination of the specimens studied by Labriola and Suriano (1998) revealed that they did not conform to the generic diagnosis of Parastrigea and their correct identification corresponds to Apharyngostrigea. Since the morphology and the metric characters of these specimens correspond to the description by Dubois (1981), we transfer these specimens to $A$. ardearum. The finding of this species in A. cocoi, $A$. $a l b a$ and $B$. ibis represents new hosts and Argentina a new geographic distribution for this parasite species.

\section{Family Diplostomidae}

Sphincterodiplostomum musculosum Dubois, 1936

\section{Taxonomic summary}

Host: Tigrisoma lineatum, rufescent tiger-heron (Ardeidae). Locality: Bellaco stream, Pirané, Formosa Province.

Site of infection: intestine.

Prevalence and intensity of infection: 1 of $1 ; 8$.

Voucher specimen deposited: MLP 5970.

\section{Remarks}

The monospecific genus Sphincterodiplostomum Dubois, 1936 is characterized by the presence of a dorsal invagination at the level of the posterior testis equipped with a sphincter. Sphincterodiplostomum musculosum was described based on immature specimens collected from the intestine of Agamia agami (Gmelin) (Ardeidae) from Brazil (Dubois, 1936, 1938). Later, unencysted metacercariae in the orbit of the eye of Hoplias malabaricus (Bloch) (Erythrinidae) and mature specimens parasitizing A. alba from northeastern Argentina were described by Szidat (1969) and Lunaschi and Drago (2006a), respectively. The finding of adult specimens of $S$. musculosum in T. lineatum represents a new host record.

Tylodelphys elongata (Lutz, 1928) Dubois, 1937

\section{Taxonomic summary}

Host: Tigrisoma lineatum, rufescent tiger-heron (Ardeidae). Locality: Bellaco stream, Pirané, Formosa Province, Argentina.

Site of infection: intestine.

Prevalence and intensity of infection: 1 of $1 ; 1$. Voucher specimen deposited: MLP 5971

\section{Remarks}

Tylodelphys elongata originally described as Alaria elongata Lutz, 1928 in Venezuela (Lutz, 1928), was reported parasitizing podicipedids, Tachybaptus dominicus (L.) from Cuba, Brazil, Venezuela and USA and Podilymbus podiceps (L.) from Cuba and USA (Travassos et al., 1969; Dubois, 1970b; Dubois and Macko, 1972; Storer, 2000). It was also recovered in ciconiids, Jabiru mycteria (Lichtenstein) from Brazil and Venezuela, and $M$. americana from Venezuela (Travassos et al., 1969; Gomes and Oliveira Rodrigues, 1981). The finding of T. elongata in $T$. lineatum represents a new host record, the first record in ardeid birds and the first report of this species in Argentina.

Dolichorchis lacombeensis Lunaschi and Drago, 2006

\section{Taxonomic summary}

Hosts: Ardea cocoi, A. alba.

Locality: Lacombe lagoon, Lezama, Buenos Aires Province.

Site of infection: intestine.

Prevalence and mean intensity: A. cocoi: 100\% (2 of 2); 45 (14-76); A. alba: $50 \%$ (2 of 4); 2.

Voucher specimen deposited: A. cocoi MLP 5972; A. alba MLP 5973

\section{Remarks}

This species was described recently by Lunaschi and Drago (2006b) parasitizing $A$. cocoi from Buenos Aires Province. The finding of this diplostomid in A. alba 
represents a new host record.

\section{Posthodiplostomum nanum Dubois, 1937}

\section{Taxonomic summary}

Hosts and localities: Ardea alba from Lacombe lagoon, Lezama, Buenos Aires Province and Clorinda, Formosa Province; Tigrisoma lineatum from Bellaco stream, Formosa Province.

Site of infection: intestine.

Prevalence and mean intensity: A. alba, Lacombe lagoon: $50 \%$ (2 of 4); 9.5 (2-17); A. alba, Clorinda: 1 of 1; 66; T. lineatum: 1 of $1 ; 10$.

Voucher specimen deposited: A. alba from Buenos Aires Province, MLP 5974; from Formosa Province, MLP 5977; T. lineatum MLP 5975.

\section{Remarks}

A wide range of birds has been reported as host of $P$. nanum in the Neotropical Region, Butorides virescens (L.) and Butorides striata striata (L.) (Ardeidae) from Brazil; Butorides virescens maculata (Boddaert) from Cuba and Colombia, Pitangus sulphuratus (L.) (Tyrannidae) and Tigrisoma lineatum marmoratum (Vieillot) (Ardeidae) from Venezuela, Busarellus nigricollis (Latham) (Accipitridae) and B. striata from Paraguay (Dubois, 1970a, 1970b, 1985, 1988; Gomes and Oliveira Rodrigues, 1981; Lamothe-Argumedo and Jaimes Cruz, 1982). In Argentina, it was reported in the Humid Pampas ecoregion parasitizing ardeid, A. a. egretta, B. striata, I. involucris, and threskiornithid, P. chihi, (Boero et al., 1972; Ostrowski de Núñez, 1973; Digiani, 2000). The finding of $P$. nanum parasitizing T. lineatum and A. alba in the Humid Chaco ecoregion represents a new geographical record.

\section{Posthodiplostomum sp.}

\section{Taxonomic summary}

Hosts: Ardea cocoi.

Locality: Lacombe lagoon, Lezama, Buenos Aires Province.
Site of infection: intestine.

Prevalence and intensity of infection: 50\% (1 of 2); 6.

Voucher specimen deposited: MLP 6013.

\section{Remarks}

The 6 specimens collected are immature and probably belong to $P$. nanum.

\section{Family Echinostomatidae \\ Paryphostomum segregatum Dietz, 1909}

\section{Taxonomic summary}

Host: Coragyps atratus, black vulture (Cathartidae). Locality: La Marcela farm, Pirané, Formosa Province. Site of infection: intestine.

Prevalence and intensity of infection: 33\% (1 of 3); 18 . Voucher specimen deposited: MLP 6010.

\section{Remarks}

Paryphostomum segregatum possesses a distribution restricted to the Neotropical Region, and was found in Brazil, Venezuela, Guyana and Paraguay parasitizing cathartid, $C$. atratus, Coragyps atratus foetens (Lichtenstein), Cathartes aura (L.), Cathartes aura ruficollis Spix, C. b. urubitinga and S. papa (Vevers, 1923; Lutz, 1928; Caballero and Díaz-Ungría, 1958; Travassos et al., 1969; Kostadinova et al., 2002). Particularly, in Argentina, it was reported in the Humid Pampas ecoregion parasitizing Phalacrocorax brasilianus brasilianus (Gmelin) by Ostrowski de Núñez (1968). The finding of $P$. segregatum parasitizing $C$. atratus in the Humid Chaco ecoregion represents a new geographical record.

\section{Petasiger sp. 1.}

\section{Taxonomic summary}

Host: Ardea cocoi

Locality: Lacombe lagoon, Lezama. 
Site of infection: intestine.

Prevalence and intensity of infection: 50\% (1 of 2); 1.

Voucher specimen deposited: MLP 6012.

\section{Remarks}

A single adult was found in the small intestine of $A$. cocoi. This specimen was not in sufficiently good condition for species determination, but can be distinguished by having a well developed head collar with 19 spines.

\section{Petasiger sp. 2.}

\section{Taxonomic summary}

Host: Coragyps atratus, black vulture (Cathartidae). Locality: La Marcela farm, Pirané, Formosa Province. Site of infection: intestine.

Prevalence and intensity of infection: 33\% (1 of 3); 2. Voucher specimen deposited: MLP 6011.

\section{Remarks}

Only 2 specimens of Petasiger sp. were found in the small intestine of $C$. atratus. These echinostomatids can be distinguished from specimens obtained from A. cocoi by having a well developed head collar with 27 spines. Further studies are needed to identify it to the species level.

\section{Family Heterophyidae}

Ascocotyle diminuta (Stunkard and Haviland, 1924)

\section{Taxonomic summary}

Host: Ardea alba

Locality: Lacombe lagoon, Lezama, Buenos Aires Province.

Site of infection: intestine.

Prevalence and intensity of infection: 25\% (1 of 4); 1 .

Voucher specimen deposited: MLP 5976

\section{Remarks}

This species was previously found in ardeid birds, $A$. alba and A. herodias from Mexico and USA (Sepúlveda et al., 1999; Scholz et al., 2001). In Argentina, it was reported parasitizing to E. thula from a Zoological Garden in Buenos Aires Province by Ostrowski de Núñez (1993). This is the first record of $A$. diminuta parasitizing wild birds from Argentina.

\section{Final comments}

Host-parasite relationships. Among the 10 digenean species collected, the diplostomids were the group best represented (4 species), followed by the echinostomatids (3 species), strigeids ( 2 species), and heterophyids (1 species). In the Humid Pampas ecoregion, infected birds harbored a mean of $3(2-4)$ digenean species; the most prevalent species were A. ardearum and P. nanum (67\%); whereas, in the Humid Chaco ecoregion, the birds harbored a mean of 2.5 (2-3) digenean species, the most prevalent species were $P$. nanum and S. musculosum (33\%).

The fish eating ardeids, A. alba, A. cocoi and T. lineatum harbored 7 digenean species whose life cycles include fishes, whereas Syrigma sibilatrix was found free of digeneans; this may be related to their terrestrial habitats and diet, which include predominantly arthropods, and occasionally amphibians and reptiles (Franz et al., 2007). Moreover, the great egrets from both ecoregions sampled were found parasitized by $A$. ardearum and $P$. nanum, whereas $A$. diminuta and $D$. lacombeensis were only recovered in the Humid Pampas ecoregion and $S$. musculosum was only found in the Humid Chaco. This suggests that this host species shows a little regional difference in feeding. Finally, the cathartid C. atratus, was found parasitized by species that were not found in the ardeids; these differences can be explained by their scavenging habits.

\section{Acknowledgements}

The authors express their gratitude to Dr Juan T. Timi, Laboratorio de Parasitología, Departamento de Biología, FCEyN, UNdMP for the loan of material described by Labriola and Suriano; Ing. Agr. Marcelo Martínez Leanes and Mr. Roberto Aranda for their help and hospitality at Centro de Pesca San Jorge, and Dr. Carlos Montoya at 
Formosa Province. The present study was funded by CIC (Res. No 578/08).

\section{Literature cited}

Barnett, J. M. and M. Pearman. 2001. Lista comentada de las aves argentinas. Lynx Edicions, Barcelona. 164 p.

Boero, J. J., J. E.Led and E. Brandetti. 1972. El parasitismo de la fauna autóctona. Revista de la Facultad de Agronomía y Veterinaria, Buenos Aires 1:17-29.

Bray, R., D. Gibson and A. Jones. 2008. Keys to the Trematoda. Vol. 3. CAB International, London. 824 p.

Bush, A. O., K. D. Lafferty, J. M. Lotz and A. W. Shostak. 1997. Parasitology meets ecology on its own terms: Margolis et al. revisited. Journal of Parasitology 83:575-583.

Caballero, E. and C. Díaz-Ungría. 1958. Intento de un catálogo de los tremátodos digéneos registrados en territorio venezolano. Memoria de la Sociedad de Ciencias Naturales La Salle 18:19-36

Gomes, D. C. and H. de Oliveira Rodrigues. 1981. Trematoda. In Aquatic Biota of Mexico, Central America and the West Indies, S. H. Hurlbert and A. Villalobos Figueroa (eds.). San Diego State University. 116-128 p.

Digiani, M. C. 2000. Digeneans and cestodes parasitic in the white-faced ibis Plegadis chihi (Aves: Threskiornithidae) from Argentina. Folia Parasitologica 47:195-204.

Drago, F. B. and L. I. Lunaschi. 2008. Description of a new species of Tylodelphys (Digenea, Diplostomidae) in the wood stork, Mycteria americana (Aves, Ciconiidae) from Argentina. Acta Parasitologica 53:263-267.

Dubois, G. 1936. Nouveaux principes de classification des Trématodes du groupe des Strigeida (Notes préliminaires). Revue Suisse de Zoologie 43:507-515.

Dubois, G. 1938. Monographie des Strigeida (Trematoda). Mémoires de la Société Neuchâteloise des Sciences Naturelles 6:1-535.

Dubois, G. 1964. Du statut de quelques Strigeata La Rue, 1926 (Trematoda). I. Bulletin de la Société Neuchâteloise des Sciences Naturelles 87:27-71.

Dubois, G. 1968. Synopsis des Strigeidae et des Diplostomidae (Trematoda). Mémoires de la Société Neuchâteloise des Sciences Naturelles 10:1-258.

Dubois, G. 1970a. Les Strigeata (Trematoda) de la collection A. Lutz. Memórias do Instituto Oswaldo Cruz 68:169-196.

Dubois, G. 1970b. Synopsis des Strigeidae et des Diplostomatidae (Trematoda). Mémoires de la Société Neuchâteloise des Sciences Naturelles 10:259-727.

Dubois, G. 1978. Notes Helminthologiques. IV. Strigeidae Railliet, Diplostomidae Poirier, Proterodiplostomidae Dubois et Cyathocotylidae Poche (Trematoda). Revue Suisse de Zoologie 85:607-615.
Dubois, G. 1981. Notes Helminthologiques V: Strigeidae Railliet, Diplostomidae Poirier et Proterodiplostomidae Dubois. Revue Suisse de Zoologie 88:227-232.

Dubois, G. 1985. Quelques Strigeoidea (Trematoda) récoltés chez des oiseaux du Paraguay par la Mission Claude Weber, automne 1983, du Muséum d'Histoire Naturelle de Genève. Revue Suisse de Zoologie 92:641-648.

Dubois, G. 1988. Quelques Strigeoidea (Trematoda) récoltés au Paraguay par les expéditions du Muséum d'Histoire Naturelle de Genève, au cours des années 1979, 1982 et 1985. Revue Suisse de Zoologie 95:521-532.

Dubois, G. and J. Macko. 1972. Contribution à l'étude des Strigeata La Rue, 1926 (Trematoda: Strigeida) de Cuba. Annales de Parasitologie Humaine et Comparée 47:51-75.

Franz I, I. Rohling Ghizoni, J. L. Berguer Albuquerque, A. Barcellos, C. Britz Hassdenteufel, F. Lohman Arend and C. Martins-Ferreira. 2007. Predação da cobra d'água Helicops infrataeniatus (Serpentes, Colubridae) pela maria-faceira Syrigma sibilatrix (Aves, Ardeidae) no sul do Brasil. Biotemas 20:135-137.

Gibson D., A. Jones and R. Bray. 2002. Keys to the Trematoda. Vol. 1. CAB International, London. 521 p.

Jones, A, R. Bray, and D. Gibson. 2005. Keys to the Trematoda. Vol. II. CAB International, London. 745 p.

Kostadinova A, C. Vaucher and D. I. Gibson. 2002. Redescriptions of two echinostomes from birds in Paraguay, with comments on Drepanocephalus Dietz, 1909 and Paryphostomum Dietz, 1909 (Digenea: Echinostomatidae). Systematic Parasitology 53:147-158.

Labriola, J. B. and D. M. Suriano. 1998. Digeneans of bird (Ardeidae) from the Monte lake, Buenos Aires, Argentina. Physis 56:1-7.

Lamothe-Argumedo, R. and B. Jaimes Cruz. 1982. Trematoda. Parasitic stages. In Aquatic Biota of Mexico, Central America and the West Indies, S. H. Hurlbert and A. Villalobos Figueroa (eds.). San Diego State University. 73-84 p.

Lunaschi, L. I. and F. B. Drago. 2006a. First report of adult specimens of Sphincterodiplostomum musculosum (Digenea, Diplostomidae). Parasitology International 55:7-10.

Lunaschi, L. I. and F. B. Drago. 2006b. Description of a new species of Dolichorchis (Digenea: Diplostomidae) in the cocoi heron, Ardea cocoi (Aves, Ardeidae), from Argentina. Acta Parasitologica 51:47-50.

Lunaschi, L. I. and F. B. Drago. 2009. Digenean parasites of six species of birds from Formosa province, Argentina. Revista Mexicana de Biodiversidad 80:39-46.

Lunaschi, L. I., F. Cremonte and F. B. Drago. 2007. Checklist of digenean parasites of birds from Argentina. Zootaxa 1403:136.

Lutz, A. 1928. Estudios de zoología y parasitología Venezolanas. Universidad Central de Venezuela, Caracas. 133 p.

Ostrowski de Núñez, M. 1968. Estudios sobre la fauna 
parasitaria del biguá, Phalacrocorax o. olivaceus. I. Trematodes pertenecientes a las familias Cathaemasidae y Echinostomatidae. Revista del Museo Argentino de Ciencias Naturales Bernardino Rivadavia, Parasitología, 1:131-152.

Ostrowski de Núñez, M. 1973. Sobre el ciclo biológico de Posthodiplostomum nanum Dubois, 1937 (Trematoda, Diplostomatidae). Physis 32:121-132.

Ostrowski de Núñez, M. 1989. The life history of a trematode, Apharyngostrigea simplex (Johnston, 1904), from the ardeid bird Egretta thula in Argentina. Zoologischer Anzeiger 222:322-336.

Ostrowski de Núñez, M. 1993. Life history studies of heterohyid trematodes in the Neotropical Region: Ascocotyle (Phagicola) diminuta (Stunkard \& Haviland, 1924) and A. (P.) angrense Travassos, 1916. Systematic Parasitology 24:191-199.

Pérez Vigueras, I. 1944. Trematodes de la Super-Familia Strigeoidea; descripción de un género y siete especies nuevas. Revista de la Universidad de la Habana 52-54:294-314.

Scholz, T., M. L. Aguirre-Macedo and G. Salgado-Maldonado. 2001. Trematodes of the family Heterophyidae (Digenea) in Mexico: A review of species and new host and geographical records. Journal of Natural History 35:1733-1772.

Sepúlveda, M. S., M. G. Spalding, J. M. Kinsella and D. J. Forrester. 1999. Parasites of the great egret (Ardea albus) in Florida and a review of the helminths reported for the species. Journal of the Helminthological Society of Washington 66:7-13.

Storer, R. W. 2000. The metazoan Parasite fauna of grebes (Aves: Podicepediformes) and its relationship to the birds biology. Miscellaneous Publications, Museum of Zoology, University of Michigan 188:1-90.

Szidat, L. 1928. Zur Revision der Trematodengattung Strigea Abildgaard. Zentralblatt für Bakteriologie, Parasitenkunde, Infektionskrankheiten und Hygiene 105:204-215.

Szidat, L. 1929. Beiträge zur Kenntnis der Gattung Strigea (Abildg.). I Allgemeiner Teil: Untersuchüngen Über die Morphologie, Physiologie und Entwicklüngsgeschichte der Holostomiden Nebst Bemerkungen Über Die Metamorphose Der Trematoden Und Die Phylogenie Derselben. Zeitschrift für Parasitenkunde 1:612-764.

Szidat, L. 1969. Structure, development, and behaviour of new strigeatoid. Metacercariae from subtropical fishes of South America. Journal of the Fisheries Research Board of Canada 26:753-86.

Travassos, L., J. F. Teixeira de Freitas and A. Kohn. 1969. Trematódeos do Brasil. Memórias do Instituto Oswaldo Cruz 67:1-886.

Vevers, G. M. 1923. Some new and little known helminths from British Guiana. Journal of Helminthology 1:35-45. 
